\title{
Allocation of Foreign Aid in a Segmented International Context
}

\author{
S. I. COHEN
}

\section{INTRODUCTION}

Research on the topic of distribution of foreign aid among recipients is regaining momentum. This is understandable in the light of the knowledge that presently the richest 40 percent of the developing world receives twice as much aid per capita as the poorest 40 percent [UNDP (1994)], while once upon a time foreign aid was sought to accomplish exactly the opposite.

The distribution of official development assistance (ODA) is conventionally studied in terms of two models: the 'recipient needs' model and the 'donor interest' model. In the first, foreign aid flows are seen to satisfy the socio-economic needs of the recipient countries. In the second, national interests of donors, whether these are military, political or commercial, are seen to determine the direction and size of the foreign aid.

Empirical studies were made to ascertain and understand whether, on balance, foreign aid is motivated by recipient need or donor interest. There is one class of studies, for example, Mcgillivray (1989), which estimates for donors a compound measure of their allocation bias. The other class of studies, i.e., Maizels and Nissanke (1984) and Grilli and Riess (1992), employs regression analysis to explain allocation of foreign aid by representative variables of recipient need and donor interest.

Because the primary pursuit of these studies was to give an overall judgement on foreign aid motivations, insufficient attention was given to differentiations among donors, between recipients, and over time. The allocation policies of donors can be observed to differ between large donors and small donors, whereby the two types of donors are often tied to different groups of recipient countries. Moreover, other arguments than recipient need and donor interest, such as historic and geographical ties and the changing world political order, play important roles.

S. I. Cohen teaches in the Faculty of Economic Sciences, Erasmus University, Rotterdam, The Netherlands.

Author's Note: The author acknowledges the contributions of N. de Jong and M. de Zeeuw with regard to computational matters. 
This paper elaborates on and extends the above two classes of studies quoted to consider the differentiation between donor types. In Sections 2 and 3, we shall show some empirical results for a small donor like The Netherlands, vis-à-vis larger donors, and examine the most recent trends of ODA of this country. Section 4 will briefly present the case for looking at foreign aid allocations as transactions with economic and non-economic aspects in a segmented international context and with specific recipients tied to specific donors. Finally, we comment on several implications.

\section{COMPOUND MEASURES OF DONOR MOTIVES}

McGillivray (1989) developed a measure of the progressiveness of the aid of a particular donor, $i$. Aid progressiveness is seen as the extent to which the donor willingly chooses a geographical distribution of its aid which gives more aid to the poorest and most needy among the recipients, $j=1, \ldots, J$. The criteria for the poorest and most needy are income per head and population size. Countries with lower income per head and bigger populations are assumed to require more aid. The developed measure, which can be called donor motive coefficient, is denoted by $D M C_{i t}$, for donor $i$ in year $t$, and is defined in terms of aid, $A I D$, population, $P O P$, and income per capita, $Y$, as follows:

$$
\begin{aligned}
& D M C_{i t}=\sum_{j-1}^{J} W_{j t}\left[\frac{\left(A I D_{i j} / P O P_{j}\right) t}{\sum_{j}\left(A I D_{i j} / P O P_{j}\right) t}\right] \quad \ldots \quad \ldots \\
& \begin{array}{llllll}
W_{j t}=\frac{(Y j-Y \max ) t}{Y \min -Y \max ) t} & \ldots & \ldots & \ldots & \ldots & \ldots
\end{array}
\end{aligned}
$$

$\left(A I D_{i j} / P O P_{j}\right)_{t}=$ aid disbursed by donor $i$, and received by recipient $j$, expressed per head of recipient $j$, in year $t$;

$W_{j t}=$ weight of the recipient $\mathrm{j}$ relative to other recipients, in year $t$; and

$Y_{j}, Y_{\min }, Y_{\max }=$ GNP per head of recipient country $j$, lowest GNP per head of all recipient countries, and highest GNP per head of all recipient countries, respectively.

It follows from the above definition of $D M C$ that the value of this coefficient is the highest for the donor who follows a progressive distribution and the lowest for the donor who distributes its aid regressively to the recipients. A value of $D M C_{i}=1.0$ is realised if the motivations behind aid of donor $i$ crystallise in the allocation of all its aid to the poorest recipient, such a country having a low income per head and a large population, in which case the allocation term in Equation (1) would equal one and the 
weight term $W_{j}$ would equal one too. A value of zero is obtained for $D M C_{i}$ in case the donor $i$ allocates all its aid to the richest recipient, such a country having a high income per head and a small population.

McGillivray calculated the donor motive coefficient for OECD donor countries for 1969-84, and obtained the averages, the highest and the lowest values over the whole period, as in Table 1. It is noted that the score for the larger donor countries is between .64 and .86; these include the USA, FRG, Italy, France, Japan, and UK, while the score for the smaller donor countries ranges between .88 and .94 , including the four Scandinavian countries, two Benelux countries, Switzerland, and Canada.

Table 1

Donor Motive Coefficient $\mathrm{DMC}_{\mathrm{i}}$ (Value of one indicates a perfectly progressive allocation of foreign aid)

\begin{tabular}{|c|c|c|c|c|c|c|c|c|c|}
\hline Large Donors & USA & FRG & Italy & France & Japan & UK & & & Average \\
\hline \multicolumn{10}{|l|}{ Average } \\
\hline 1969-84 & .64 & .77 & .77 & .78 & .82 & .86 & & & .77 \\
\hline Highest Year & .85 & .86 & .94 & .85 & .91 & .92 & & & .89 \\
\hline Lowest Year & .44 & .67 & .46 & .71 & .68 & .79 & & & .62 \\
\hline \multicolumn{10}{|l|}{ Results } \\
\hline 1992-93 & .48 & .61 & .95 & .95 & .88 & .97 & & & .81 \\
\hline $\begin{array}{l}\text { Small } \\
\text { Donors }\end{array}$ & $\begin{array}{c}\text { Swe- } \\
\text { den }\end{array}$ & Canada & $\begin{array}{l}\text { Nether- } \\
\text { lands }\end{array}$ & $\begin{array}{l}\text { Switzer } \\
\text { - lands }\end{array}$ & $\begin{array}{l}\text { Nor- } \\
\text { way }\end{array}$ & $\begin{array}{l}\text { Den- } \\
\text { mark }\end{array}$ & Finland & $\begin{array}{c}\text { Belgiu } \\
\text { m }\end{array}$ & Average \\
\hline \multicolumn{10}{|l|}{ Average } \\
\hline 1969-84 & .88 & .88 & .88 & .88 & .92 & .93 & .93 & .94 & .91 \\
\hline Highest Year & .93 & .92 & .92 & .93 & .95 & .94 & 1.00 & .98 & .95 \\
\hline Lowest Year & .80 & .75 & .77 & .77 & .90 & .91 & .88 & .89 & .83 \\
\hline \multicolumn{10}{|l|}{ Results } \\
\hline 1992-93 & .96 & .92 & .98 & .96 & .91 & .98 & .94 & .97 & .95 \\
\hline
\end{tabular}

Source: Rows 1, 2, 3 from McGillivray (1989).

Rows 4 summarises results from our own calculations for 1992-93, calculated from data on foreign aid given in OECD (1994), and data on income per capita from the World Bank. Recipient countries with populations below one million were excluded from the application.

The results are indicative of different motivations behind the groups of large and small donors, the large donors appearing to be regressive in their foreign aid allocations, while the smaller donors appearing to promote progressive allocations.

We have applied the exercise for 1992-93, giving results in the fourth row. In these applications, it is noted that the proportion of total ODA covered by the term $A I D_{i}$ is different per donor $i$. This was also the case in McGillivray. For most donors, the coverage was about 70 percent or above of the ODA with the exception of Sweden and 
France, where the published ODA data allowed a coverage of 64 and 40 percent, respectively.

The results obtained for 1992-93 show that the donor motive coefficient for the large donors is biased towards regressive allocations—average value 0.81 -as compared to that of small donors who allocate their aid more progressively-average value 0.95 . The very well observed difference in the distribution pattern between large and small donors can be looked upon as the result of contrasting motives, with donor interest dominant among the large members of DAC and recipient needs among the small members. But other interpretations, which we shall address in a later section, are plausible. In both cases, there has been, on the average, a change over the years towards a more equitable distribution of foreign aid to recipients, which can be due to a relaxation in political confrontations among western donors, and in particular among the larger donors.

\section{REGRESSION ANALYSIS OF DONOR INTEREST AND RECIPIENT NEEDS}

In a comprehensive study of the issue, Maizels and Nissanke (1984) fitted crosscountry regressions to foreign aid received by some 80 developing countries in 1969-70 and 1979-80. In a stepwise regression they used, on the one hand, explanatory variables representing the recipient needs (GDP per capita, GNP growth, trade deficit, population, and relative shortfalls in basic needs), and on the other hand, variables belonging to the sphere of donor interest such as arms transfer, regional interest, private investment, and strategic imports. The results for the major bilateral aid donors, summarised in Table 2, show that the motivations are heavily dominated by donor interest, for the USA and France practically entirely so, while for the UK, Japan, and the FRG to lesser extents. The results indicated also that additional explorations, beyond recipient needs and donor interests, are required.

Table 2

Relative Importance of Recipient Needs and Donor Interest in the Foreign Aid of Large Donors, 1979-80

\begin{tabular}{lccccc}
\multicolumn{5}{c}{ Foreign Aid of Large Donors, 1979-80 } \\
\hline & USA & FRG & France & Japan & UK \\
\hline $\begin{array}{l}\text { Adjusted } R^{2} \\
\begin{array}{l}\text { Percentage of Explained } \\
\text { Variance Due to: }\end{array}\end{array}$ & 0.97 & 0.56 & 0.89 & 0.38 & 0.63 \\
$\quad$ Recipient Needs \% & 0.1 & 31.6 & 1.6 & 18.9 & 9.8 \\
Donor Interest \% & 99.9 & 68.4 & 98.4 & 81.1 & 90.2 \\
\hline
\end{tabular}

Source: Maizels and Nissanke (1984).

A later study by Grilli and Riess (1992) for members of the European Community (EC) for 1971-88 confirms the findings that the distribution of bilateral 
foreign aid to recipients has been largely driven by the commercial interests of the major donors of the EC.

We shall now investigate how far cross-section regressions for the small donor countries give contrasting results to those so far found for the large donor countries. We have selected the case of The Netherlands for this examination. The period examined for this small donor will be that of 1968-88, which is longer than but encompasses the period for which the larger donors were studied.

The two official objectives of Dutch Development Cooperation (DDC), as explicitly defined in 1983-84, were: (1) poverty alleviation and (2) strengthening of the economy in order to enhance self-reliance. These two lines of policy were and are still thought to be interrelated; structural poverty alleviation is regarded as being conditional on strengthening of the economy, whereas growth is necessary to alleviate poverty. Since then these objectives were elaborated to include female participation and environmental conservation.

The machinery for allocating Dutch foreign aid is the Directorate General of International Cooperation, which forms part of the Ministry of Foreign Affairs. But, allocational decisions cannot be taken fully in isolation from what happens in other departments within the Ministry, and in several other ministries. Allocational decisions have also to consider parliamentary opinion; the same goes for public opinion. Pressure groups and lobbying circles play a significant role, too. Finally, even the Directorate itself cannot be regarded as a coherent unit. For instance, the multilateral programme is carried out more or less separately from the other programmes. Furthermore, since the organisation of bilateral assistance takes place at the level of regional country desks, these desks are known to compete energetically, successes and failures in reallocations very often tied to the person in office and the ambassador in the recipient's capital.

In terms of ODA as a percentage of the GNP, the Dutch figure was 0.81 percent in 1993, down from 0.86 percent in 1992; which is still among the highest of the DAC countries. The bilateral assistance programme constitutes a large category of Dutch foreign aid, about 20 percent. In the eighties, there used to be extensive and long-term cooperation with 10 so-called concentration countries and 4 regions, viz., the Sahel, Southern Africa, Central America, and the Andes region. The concentration countries were Bangladesh, India, Indonesia, North Yemen, Pakistan, Sri Lanka, Egypt, Kenya, Sudan, and Tanzania. Apart from this, there is a special development relationship with Suriname. ${ }^{1}$ Because the explanatory models which will be developed in this paper will be restricted to the bilateral allocations, it is not necessary to discuss the other categories of foreign aid, although decisions on these may sometimes have a bearing on the distribution of bilateral assistance programmes for the recipient countries. A more elaborate study of such matters is reported in Cohen and De Jong (1990).

We shall restrict our analysis to explaining allocations to the ten countries

${ }^{1}$ Although the recent Dutch policy document gives explicit reasons for concentrating aid on a limited number of countries, yet the concentration policy of the eighties has been somewhat relaxed and the bilateral assistance goes currently to 56 countries. 
mentioned, which have been concentration countries throughout 1968-88, or at least during the greater part of this period. These countries were not removed from the list of concentration countries when a policy revision took place in the early 1980s. Aid received by each of these ten countries for the 21 individual years form the data-set for testing two equations. One equation aims at explaining the absolute level of foreign aid received by the recipient country, $A I D_{j t}$ and the other is for explaining a recipient country's annual share in the annual total allocation to the ten recipients, $A I D_{j t} / \sum A I D_{j t}$.

The explanatory variables belong either to the recepient country and are meant to represent the degree of need for assistance; or to the donor country, indicating donor interests in aid disbursement. There is also a third category of neutral variables, which help in explaining the allocations but do not relate to recipient need or donor interest.

There are two variables representing the recipient needs. $P O P_{j, t-1}$ is the one-year lagged population. The expectation is that the higher the population, the more aid allocations will be made to the country concerned. $Y_{j, t-1}$ is the one-year lagged level of GDP per capita in US dollars. The expectation is that the higher the income per capita, the less need there is to allocate aid to the country in question.

The analysis includes two explanatory variables of finance and trade which represent donor interest. $D S R_{j, t-1}$ is the one-year lagged debt-service ratio. Here one might expect a positive sign if it is assumed that a lower capacity of a country to service its debts will be an incentive to provide more assistance. Countries which have difficulties to service their debts are often involved in stabilisation and structural adjustment programmes of the IMF and the World Bank, however. Because such aid is given multilaterally and because the recipient is often seen in such situations to be less credible, donor interest is served by less involvement of the recipient in the bilateral programme. In that case, the expected sign

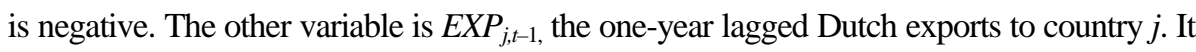
is generally assumed that aid transfers stimulate exports from the donor country [Marsden and Roe (1983)]. If the past level of Dutch exports to a recipient is already high, the opportunities to raise this level further are likely to be more limited than in the case of a lower past level, and from this point of view a donor is expected to be less inclined to provide assistance. For this reason, the expected sign is negative. It is also possible to maintain that aid commitment is an effective means of raising donor exports to the recipient via tied aid or contractual promotion. Once the penetration of donor exports is achieved, there may be less urge to increase aid. Such behaviour will also lead to a negative sign. Note that from the point of view of the recipient, it can be argued that a higher level of imports from the Netherlands may be an indication that the country in question is more capable of financing its imports on its own, so there will be less need to receive aid.

A few other variables are included to neutralise the data set. These variables are neutral in the sense that they do not belong to either donor interest or recipient need. NNI is net national income of the Netherlands at market prices. This variable is 
necessary to capture the capacity to provide assistance by the donor. The expected sign is positive. Furthermore, POL is a dummy variable to represent the policy reorientation of 1975, whereby Egypt, North Yeman, Sri Lanka and Sudan acquired the status of a concentration country, and the allocations to most of the other countries were revised downwards. The pre-1975 dummy takes the value 1; otherwise zero. The expected sign is negative. Finally, IND is a dummy variable to account for the special, historically determined, relationship with Indonesia; Indonesia $=1$, other $=0$.

Selected results from the first set of regression analysis are presented in Table 3. The first regression shows the recipient's population to explain about 53 percent of the variance in the allocations among recipients. Including the level of the GDP per capita raised the adjusted $R^{2}$ somewhat, but the regression coefficient for the GDP per capita showed a wrong sign. The performance of the regression improved somewhat more when such donor interest variables of the debt-service ratio and exports are incorporated. All effects of the four regressed variables now have the right Signs.

The largest improvement occurs when neutral variables are introduced as in regression (5). All coefficients are found to be significant and have the expected sign, whereas another 30 percentage points are added to the adjusted $R^{2}$.

The results seem to confirm that the official objectives of Dutch bilateral assistance, which coincide with recipient needs, are indeed the primary determinants of the allocational policies, able to explain about 55 out of 100 cases. Donor interest as represented by the debt-service ratio and exports plays a very secondary role and is able to add only a little more to the explanation, the equivalent of some 5 percent of the cases. Neutral variables, which were very often ignored in the studies of foreign aid motivations, are found to be significant in explaining the equivalent of another 30 percent of the cases.

Turning to the second set of regression analysis, which explains the allocational shares to the recipient countries over time, $A I D_{j t} / \sum_{j} A I D_{j t}$ it is necessary to write some of the explaining variables as shares to suit this set of regressions. Among the recipient needs variables, the population variable $P O P_{j, t-1}$ is re-expressed as country $j$ 's share in the total population of all countries $j$, thus $\left(P O P_{j} / \sum_{j} P O P_{j}\right)_{t-1}$. The variable of $Y_{j, t-1}$ remains the same. The donor interest variable of exports is re-expressed as country $j$ 's share in the total export of the Netherlands to countries $j$, thus $\left(E X P_{j} / \sum_{j} E X P_{j}\right)_{t-1}$. $D S R_{j, t-1}$ remains the same. The neutral values are restricted to two dummy variables of $P O L$ and $I N D$, and remain the same.

Regression (1) shows the relevance of the recipient needs model, Table 4. The share of population of the recipient, in the total population of the 10 concentration countries, is shown to explain about 40 percent of the variance. In contrast, the GDP per capita in regression (2) did not offer any additional explanation.

With reference to the donor interest variables, regressions (3) and (4) show an improvement in the adjusted $R^{2}$ with the introduction of the debt-service ratio and the export share, but the regression coefficients do not have the expected sign, which weakens the case for a donor interest argument. 
Table 3

Explaining the Absolute Allocation of Dutch Bilateral Assistant to Ten Recipients for the Years 1968-1988

\begin{tabular}{|c|c|c|c|c|c|}
\hline Explanatory Variables & $\begin{array}{c}\text { Regression } \\
1\end{array}$ & $\begin{array}{c}\text { Regression } \\
2\end{array}$ & $\begin{array}{c}\text { Regression } \\
3\end{array}$ & $\begin{array}{c}\text { Regression } \\
4\end{array}$ & $\begin{array}{c}\text { Regression } \\
5\end{array}$ \\
\hline \multicolumn{6}{|l|}{$\begin{array}{l}\text { Recipient Need } \\
\text { Variables }\end{array}$} \\
\hline Population $P O P_{j, t-1}$ & $\begin{array}{r}0.228 \\
(14.36)\end{array}$ & $\begin{array}{r}0.229 \\
(15.15)\end{array}$ & $\begin{array}{r}0.229 \\
(15.26)\end{array}$ & $\begin{array}{r}0.199 \\
(12.13)\end{array}$ & $\begin{array}{r}0.216 \\
(26.61)\end{array}$ \\
\hline $\begin{array}{l}\text { Income per Capita } \\
Y_{j, t-1}\end{array}$ & & $\begin{array}{l}0.014 \\
(1.99)\end{array}$ & $\begin{array}{l}0.015 \\
(2.14)\end{array}$ & $\begin{array}{l}-0.000 \\
(-0.04)\end{array}$ & $\begin{array}{l}-0.044 \\
(-8.66)\end{array}$ \\
\hline \multicolumn{6}{|l|}{$\begin{array}{l}\text { Donor Interest } \\
\text { Variables }\end{array}$} \\
\hline $\begin{array}{l}\text { Debt Service Ratio } \\
D S R_{j, t-1}\end{array}$ & & & $\begin{array}{l}-0.536 \\
(-1.73)\end{array}$ & $\begin{array}{l}-0.577 \\
(-1.92)\end{array}$ & $\begin{array}{l}-0.581 \\
(-3.79)\end{array}$ \\
\hline Exports $E X P_{j, t-1}$ & & & & $\begin{array}{r}0.144 \\
(3.86)\end{array}$ & $\begin{array}{l}-0.072 \\
(-3.52)\end{array}$ \\
\hline \multicolumn{6}{|l|}{$\begin{array}{l}\text { Neutral Variables, } \\
\text { Dummies }\end{array}$} \\
\hline Net National Income & & & & & 0.301 \\
\hline Netherlands NNI & & & & & $(8.97)$ \\
\hline Policy Reorientation & & & & & -22.119 \\
\hline Year POL & & & & & $(-4.10)$ \\
\hline Special Relation & & & & & 100.156 \\
\hline Indonesia IND & & & & & $(18.71$ \\
\hline
\end{tabular}

Regression Statistics

Adjusted $R^{2}$ .525 .560 .567 .599 .905

Sources: GDP and population in variables come from the Penn World Table (Mark 4); debt-service ratios are taken from World Bank, World Debt Tables; Export figures from IMF, Directions of Trade Statistics yearbook; net national income from Dutch Central Bureau of Statistics, Nationale Rekeningen (National Accounts).

${ }^{*} T$-values in brackets. Coefficients of the constant term a, not shown in the table, are not always significant. 
Table 4

Explaining the Allocational Shares of Dutch Bilateral Assistance to Ten Recipients for the Years 1970-1988

\begin{tabular}{|c|c|c|c|c|c|c|c|}
\hline Explanatory Variables & $\begin{array}{l}\text { Regres- } \\
\text { sion } 1\end{array}$ & $\begin{array}{l}\text { Regres- } \\
\text { sion } 2\end{array}$ & $\begin{array}{l}\text { Regres- } \\
\text { sion } 3\end{array}$ & $\begin{array}{l}\text { Regres- } \\
\text { sion } 4\end{array}$ & $\begin{array}{l}\text { Regres- } \\
\text { sion } 5\end{array}$ & $\begin{array}{l}\text { Regres- } \\
\text { sion } 6\end{array}$ & $\begin{array}{l}\text { Regres- } \\
\text { sion } 7\end{array}$ \\
\hline \multicolumn{8}{|l|}{$\begin{array}{l}\text { Recipient Need } \\
\text { Variables }\end{array}$} \\
\hline $\begin{array}{l}\text { Population Share } \\
\qquad\left(P O P_{j} / \sum_{j} P O P_{j}\right)_{t-1}\end{array}$ & $\begin{array}{r}0.389 \\
(10.94)\end{array}$ & $\begin{array}{r}0.386 \\
(10.75)\end{array}$ & $\begin{array}{r}0.387 \\
(10.95)\end{array}$ & $\begin{array}{l}0.267 \\
(7.64)\end{array}$ & $\begin{array}{r}0.363 \\
(12.41)\end{array}$ & $\begin{array}{r}0.360 \\
(14.90)\end{array}$ & $\begin{array}{r}0.359 \\
(14.73)\end{array}$ \\
\hline Income per Capita & & -0.002 & -0.001 & -0.003 & -0.004 & -0.005 & -0.005 \\
\hline$Y_{j, t-1}$ & & $(-1.23)$ & $(-0.84)$ & $(-2.01)$ & $(-3.62)$ & $(-3.68)$ & $(-3.95)$ \\
\hline \multicolumn{8}{|l|}{$\begin{array}{l}\text { Donor Interest } \\
\text { Variables }\end{array}$} \\
\hline Debt Service Ratio & & & -0.173 & -0.163 & -0.091 & -0.092 & \\
\hline$D S R_{j, t-1}$ & & & $(-2.58)$ & $(-2.74)$ & $(-1.94)$ & $(-1.98)$ & \\
\hline Export Share & & & & 0.460 & -0.011 & & \\
\hline$\left(E X P_{j} / \sum_{j} E X P\right)_{t-1}$ & & & & (7.16) & $(-0.15)$ & & \\
\hline \multicolumn{8}{|l|}{$\begin{array}{l}\text { Neutral Variables, } \\
\text { Dummies }\end{array}$} \\
\hline Policy Reorientation & & & & & -3.098 & -3.107 & -3.081 \\
\hline Year POL & & & & & $(-2.66)$ & $(-2.70)$ & $(-2.65)$ \\
\hline Special Relation & & & & & 21.239 & 21.022 & 21.404 \\
\hline Indonesia IND & & & & & (10.29) & $(14.02)$ & (14.27) \\
\hline
\end{tabular}

Regression Statistics

\begin{tabular}{llllllll} 
Adjusted $R^{2}$ & .396 & .403 & .422 & .554 & .730 & .731 & .727 \\
\hline
\end{tabular}

Sources: Same as Table 3.

Introducing the neutralising dummies for the special relationship with Indonesia, $I N D$, and for the policy reorientation of 1975, POL improved the explanatory power of the regression substantially and showed a correct negative sign for the export share but not a significant regression coefficient. Therefore, in regression (6) we excluded the export share, which led to an improvement of the adjusted $R^{2}$ and rendered the effect of the debt-service ratio almost significant. To assess the effect of excluding the debtservice ratio as well, we ran an additional regression (7). This left unaffected the coefficients of the explanatory variables and the adjusted $R^{2}$. Thus it is appropriate to leave out the debt-service ratio as well. 
The conclusion is obvious: recipient needs as represented by the population share and income per capita seem to be the principal determinants of the allocational shares of the Dutch bilateral assistance programme. Donor interest can be viewed as an irrelevant motive in the foreign aid allocations of a small donor country such as The Netherlands.

Next to that historical, geographical, and cultural considerations can play a significant role in determining the preferences of a 'patronising' donor for 'patronised' recipients, and consequently the distributional pattern of foreign aid.

Results of Tables 3 and 4 demonstrate the relevance of these neutralising factors for a country like The Netherlands, and likely for other small donors with a colonial history. Special relationships between a donor and a recipient hold for the larger donors, too, and perhaps more significantly because they can afford to. These factors weaken the dichotomic explanation of ODA allocations in terms of donor interest and recipient needs.

\section{MUTUAL DESTINY}

The results obtained can be interpreted as giving support to the hypothesis that large donors follow primarily a donor interest motivation while small donors consider primarily the recipient needs. The problems with this interpretation are that a decisionmaking context is assumed which is unified, conscious, and total. Furthermore, it is assumed that the decision-makers in the large and small donors have different motivations, or, in other words, different decision functions. Given the multi-level complexities of decisions on foreign aid, there is little reason to believe that there is any optimisation taking place, neither can some actors (small donors) be assumed to be more altruistic than large donors.

A country by country look at the distribution of foreign aid will give support to the alternative view that there are two types of ODA allocations. The first type of allocation is characterised by about one-to-one coupling of a given recipient to a given donor, which is very much based on matters of common language, historical ties, and geographical location, which are further substantiated by mutual consultations between donors. It is well-known that the French-speaking African countries receive their ODA predominantly from France. Bijective links also exist between specific historical/ regional countries in South America as recipients, and Spain and the USA as donors. Furthermore, limiting the analysis to the 15 largest aid flows for each of the 24 DACmembers, it can be stated that Australia takes care of Papua New Guinea, Italy of Albania, the Netherlands of Sudan, UK of Ghana, Switzerland of Jordan, etc. Table 5 suggests that once such couplings were started for whatever reason, they are reinforced in time by the mutual consent of DAC members. There is an economic justification of a one-to-one coupling. The donor established first, particularly in a small country recipient, has much lower transaction costs than the other donors. To be clear, the 
Table 5 
Table 5 
economic justification is often embedded in a historic or geographical context, which is mutually endorsed by the contending donors. ${ }^{2}$

The second type of allocations is untied, whereby more donors go to one recipient. The density of the concentration (number of donors in the recipient country) depends on the relative attractiveness of the recipient, whether this be strategic, political, environmental, or economic. Recipients who have gone through wars or internal upheavals, and where peace and stability are highly valued by the world community, receive more attention than others, as can be observed from the larger number of donors and aid per recipient population in such countries as Mozambique and Egypt with ten or more donors, or Nicaragua and Somalia with somewhat less donors. These are strategically attractive countries.

Among recipients which in recent history were politically interesting and were led by highly esteemed statesmen with a development orientation are Tanzania and Zambia, having well above ten donors. Countries like Zimbabwe and Kenya will also fit here; they are also environmentally attractive to foreigners. The fact that the attractive leaderships which were once present are now absent does not count against the costsaving donor-recipient linkages which were developed in the past. Exit of the established donor from a particular recipient context is usually seen to be very costly and politically non-defendable.

Finally, there are a number of economically significant recipients with populations of 100 millions or more, who, because of their sheer size, are and remain attractive to most donors. Among these countries are China (with 15 donors) and India, Bangladesh, Indonesia, Pakistan, and the Philippines somewhat smaller. In spite of the large sums of aid which these recipients get, the amount per capita and the aid/income percentage are among the lowest, 0.6 to 2.0 percent. Concentrations of donors in these recipients are a reflection of the current and expected significant roles of such countries as China and India in the world economy.

A good practice in applied analysis is to clean the given statistics from distortive definitions. This we did to ODA statistics of 1992-93, too, giving as a result Table 5. According to ODA statistics, Israel is counted as a recipient (USA and Germany as the donors). Such ODA is of a different character. As the income per capita of Israel is higher than that of several DAC donors, it is high time to delete it from ODA recipients. Similar arguments apply for counting South Korea as a recipient (Japan is donor), as well as Argentina, Brazil, Mexico (USA, Spain, and Portugal are the donors). These

${ }^{2}$ Of course, special bilateral relations of a historic, geographic, etc., nature have been observed as early as 1965, and probably before. The 1965 review Development Assistance Efforts and Policies of the DAC (OECD) notes: “Assistance from Belgium, France, Portugal, and the United Kingdom continues to be largely directed to those areas and countries which had until recently, or still have, special links of a linguistic, monetary, or commercial character. Italy, Japan, and the Federal Republic of Germany have had flows established by reparations arrangements. Nevertheless, these forces of historic or geographic determinism seem to be weakening” (p. 41, 43). As can be verified from this paper, these forces are still very significant in explaining the flows. 
countries have incomes per capita which are 50 times (or more) those of the poorest recipients. These countries include the newly emerging markets and thus capture a fair share of the world private capital flow. ODA is hardly relevant here.

There is need to revise and limit the list of ODA recipients. Table 5 excludes officially recognised recipients with income per capita above \$2000. This maximum income is still about 25 times that of the poorest recipient $\left(Y_{\max }=\$ 2000\right.$ per capita, $Y_{\min }$ $=\$ 80$ per capita).

\section{CONCLUSIONS}

In this paper we obtained results which support the hypothesis that large donor countries distribute foreign aid regressively while small donors distribute progressively. The Netherlands, an example of a small donor, was particularly shown to have a progressive distribution.

The results are interpreted by some to reflect donor interest motivations for the large donors and recipient needs motivations for the small donors. This interpretation is disputable in view of the absence of a unified, conscious or total decision-making framework according to which the donor operates.

A country-by-country analysis supports a combination of evolutionary elements with mutual consultations between donors, cost minimisation by the donors, and economic prospects of the recipient; all these determining the present allocation patterns irrespective of which donor it is.

\section{REFERENCES}

Cohen, S. I, and N. de Jong (1990) Allocation of Dutch Development Assistance: An Explanatory Approach. Growth Dynamics University Institute. Paper presented to the VIth General Conference of the European Association of Development Institute, Oslo.

Grilli, E., and M. Riess (1992), EC Aid to Associated Countries: Distribution and Determinants. Weltwirtschaftliches Archiv 128: 202-220.

Maizels, A., and M. K. Nissanke (1984) Motivations for Aid to Developing Countries. World Development 12: 9 879-900.

Marsden, K., and A. Roe (1983) The Political Economy of Foreign Aid. A World Bank Perspective. Labour and Society 8:1.

McGillivray, M. (1989) The Allocation of Aid among Developing Countries: A MultiDonor Analysis Using a Per Capita Aid Index. World Development 17:4 561-568.

OECD (1994) Development Cooperation. Efforts and Policies of the Development Assistance Committee. Paris: OECD.

UNDP (1994) Human Development Report 1994. Oxford: Oxford University Press. 